\title{
Financial literacy as a key factor for an individual's social and economic well-being
}

\author{
Tatyana Filippova ${ }^{1, \mathrm{a}}$, Elmira Kashapova ${ }^{1}$, and Svetlana Nikitina ${ }^{1}$ \\ ${ }^{1}$ Tomsk Polytechnic University, 634050 Lenin Avenue, 30, Tomsk, Russia
}

\begin{abstract}
Financial literacy is reviewed in the article as a factor influencing any individual's well-being. Characteristics of a financially competent individual are defined. Behavioral mistakes impeding rational decision-making are outlined. Structures bearing the signs of financial pyramids are described as an example of their participants' cognitive limitations. The importance of creating a common information area is stressed. This process is aimed at remedying negative consequences for all economic agents and preventing inefficient financial decisions when executing financial transactions. The major task of the process is to incorporate information about social and economic activity of institutions (state, business and non-governmental) and population in the common information area. Therefore, every economic agent will get prompt and trustworthy information. It will encourage an individual to make financially adequate decisions. The article also presents fundamental solutions for improving individuals' well-being when raising their financial literacy
\end{abstract}

\section{Introduction}

In the modern society the issues of well-being fall outside the limits of science and turn to be some of the most significant and promising ones appealing to both individuals and society. Considering new tendencies of the crisis manifestations in the world economy the issue of well-being becomes politically, economically and socially urgent.

Under current conditions of the global economy, sustainable social and economic development of a country and improvement of people's well-being depend on many factors. Of special importance is financial literacy of both professionals and great masses of population Therefore, a vital task of the state is the creation of a common information area, helping an individual make deliberate financial decisions.

Well-being, in particular social and economic one, is a key success factor in the society. For this reason, income is a moderately-strong predictor of a judgmental estimate of the living standard. Thus, high income, its positive dynamics and subjective income satisfaction is an important sign of a high level of well-being.

In a range of countries it is found that a person's estimate of her/his material wellbeing, firstly, her/his income, is an important evidence of life perception and satisfaction $[1,2]$. It means that society's well-being is a factor mediating the relation between a person's income and her/his well-being [3].
The problem of social and economic well-being is especially urgent in the countries, undergoing serious transformations, e.g. transition toward a market economy and development of democratic political institutions [4, 5]. This is an overriding issue in Russia where the majority of its population has low income, where money is viewed as an important life value and well-being is considered to be an integral part of the population's quality of living.

Thus, it is necessary to emphasize the importance of measuring the level of population's financial literacy. Raising individuals' financial literacy (young, retired people, and economically active population) encourages making wise decisions, minimizes risks, thus, furthering people's financial safety. Low level of financial literacy and lack of understanding personal finances can result not only in bankruptcy, but also in inadequate planning of income upon retirement, financial fraud vulnerability, increasing debts and social problems, including depression.

\section{Materials and methods}

Setting of the problem revealed the following contradiction. On the one hand, currently, Russian society is being transformed within the framework of the country's sustainable economic development. On the other hand, formation of different financial structurers resembling financial pyramids and low level of the

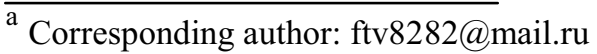


population's financial literacy short-circuit the country's development. Development of the financial sector intended for improving an individual's life and his wellbeing is restricted by individual's inability to apply these innovations, due to his financial illiteracy. Lack of knowledge also causes behavioral mistakes, namely, confusion of a financial pyramid and a financial institution. Therefore, we think that the only solution is creating mechanisms on raising financial literacy and reducing the amount of financial structures resembling financial pyramids. The aim of the research is to describe the impact of negative consequences resulting from an individual's financial illiteracy on his well-being using the example of participation in financial schemes resembling financial pyramids. It will allow indicating the guidelines for developing the informational aspect aimed at reducing the number of financially ignorant individuals. Consequently, the aims of the research are as follows: to define the concept of well-being, to outline characteristics of a financially literate individual, to determine his behavioral mistakes leading to financially inadequate decision-making, to describe financial structures resembling financial pyramids, to develop and present guidelines for raising an individual's financial literacy. The structural-functional method and the method of scientific assessment were used for analyzing financial awareness as a key factor of an individual's economic well-being.

\section{Results and discussion}

There is no consensus of opinion among scientists $[6,7]$ when describing the phenomenology of well-being, outlining its object field, defining this notion, revealing factors, influencing its structural organization consistency. Let us consider financial literacy as a key factor affecting an individual's well-being.

Well-being is defined as the result of the process aimed at achieving the good things of life, i.e. everything which can provide for a man's everyday life necessities. It must be noted that an individual's well-being depends both on internal (an individual himself), and external conditions (environment). On the one hand, it is his economical behavior (financial literacy); on the other hand, social and economic factors (economic development of the state and information system development intended for creating a common information area). In this regard, let us refer to financial literacy as an important factor of a man's social activity, conditioning his social and economic well-being. The given condition provides for an individual's psychoemotional state without deviances (life without troubles, stresses and negative developments), as well as material wealth.

It is to be noted, that financial literacy is a complex area, calling for understanding key financial notions and using information for making reasonable decisions, which contribute not only to people's well-being, but also to economic security. Among the key financial notions are decision-making on expenditures and savings, choosing relevant financial instruments, budget planning, and accumulating money for future aims, e.g., getting education or secured golden years.

Today financial literacy is an integral part of the modern homo economicus's education. A high level of financial proficiency, in particular, is a good measure against a threat of fraud from unscrupulous transactors on financial markets. Meanwhile, the majority of the world's population has a low level of financial proficiency, does not understand basic financial products, cannot plan his personal budget, assess risks, which leads to inefficient decisions and financial problems. Let us refer to some research evidence on assessing the level of financial literacy. Considering the surveys of 2006 [8] it was found that $57 \%$ of the adult population in Japan does not have a general understanding of financial instruments. $42 \%$ of American parents never discuss money matters with their children. To actively participate in the world's economy, people must have an access to financial services and understand how to use them on the elementary and more advanced levels. The most urgent problem in the developing countries is an access to bank instruments allowing saving and investing available cash assets. According to the World Economic Forum [9], currently, about 4 billion of the world population does not have an access to the bank system. Some authors [10, $11,12]$ define financial literacy as an ability to make reasonable decisions and operate effectively in the sectors associated with financial management with the aim of executing life goals and plans at present and in future.

To determine the main features, illustrating the level of financial literacy, the data based on the survey findings of the National Agency for Financial Studies in 2015 [13] were analyzed. Some of the features are: a person maintains records of his income and expenses, he spends less than he earns (i.e. accumulates savings), he knows how his rights as a financial services consumer are protected (i.e. what organizations to apply), he has an "airbag" (i.e. money for emergency purposes and retirement savings), he is well informed about finances (i.e. knows where to find and how to use necessary information), he can make a sound choice of financial services. These features are the basis for "homo economicus's" rational choice. However, individual cognitive abilities are limited and not everybody has these characteristics [14]. For instance, the majority (about $20 \%$ of population) are not always able to calculate and plan their income and expenditures. Generally, people often make decisions guided by their immediate wishes, advertisements, friends' and relatives' advice, i.e. they have not true and complete information about availability and activity of governmental financial institutions and the services provided.

In fact, there emerge people who take the advantage of the majority's financial illiteracy, i.e. those members of a society who want to gain a quick profit neglecting terms of transactions. In this case individuals run the risk of revenue loss. A perfect example is their participation in financial pyramids. Usually people cannot recognize a 
financial pyramid and take it for a legal financial institution.

The reasons for gaining a quick profit are a range of social and economic problems: How to manage your finances? How to settle debts? How to achieve a family's comfortable living? How to attain all desired aims (accommodation, a car, decent pension, etc.)? How to become financially independent? Generally, unwilling to wait long individuals conclude that participation in a financial pyramid can help solve the problems.

Summarizing the above, it is to be noted that risk minimization and a good command of personal finances is a basis for financial stability which provides for individual financial security. Therefore, financial security of the population is closely connected with managing a personal debt. The latter is formed due to an increasing consumer demand, advertisements of commercial organizations and banks, inefficient household management, economic situation in the country and, naturally, financial illiteracy. Financial literacy determines an individual's well-being, as well as political, social and economic prosperity of any state. With the increase of a number of financial institutions providing financial services, the importance of awareness about market agents and legal regulations of the market performance increases. Thus, it is impossible to discuss a rapid proliferation of a long-term saving, credit, investment and insurance strategy until people learn how to choose trustworthy organizations for investing their finances.

Financial pyramids delude investors and undermine confidence in financial institutions. Generally, a financial pyramid (Ponzi schemes) is an investment business model, where investor's revenue is paid at the expense of new investors' contributions [15]. A pyramid is based on the principle of the first investor priority. Initially, people's contributions are collected. Organizers guarantee investors high revenues and low risks of a non-existent business. Having collected a certain amount of money, they pay off a share of their income to the first members of the scheme. Over time it is getting more difficult to recruit new investors. Eventually, it is no longer possible to pay off the promised revenues to the investors who joined last [16].

The first financial pyramid was organized in France at the beginning of the XVIII century. The founder of the pyramid was J. Law. Pre-requisites for creating J. Law's system were financial problems due to the government debt service, domination of mercantile ideas in the theoretical economics, a crisis in the country, and people's obsession with quick and accessible ways for economic recovery. J. Law considered financial problem solving to be a source of the state's well-being and prosperity. However, his scheme was doomed to collapse, as there was not any real investment but only redistribution of money inside the system. Participation of the great masses of financially unaware population in the campaign generated excitement and a quick collapse of the pyramid. The main features of the first financial pyramid are a promise of wealth accumulation or profit earning; an illusion of an elaborate and well-thought-out investment policy; attraction of the maximum quantity of shareholders (investors) ready to invest money; flat money. Despite attracting all finances as investments in the Mississippi campaign, investors (contributors) could not check if their money was really invested.

Another large financial pyramid was a scheme organized in 1920 by an Italian-American Ch. Ponzi. The "Ponzi scheme" provided the basis for the majority of subsequent financial pyramids. An additional characteristic of Ponzi scheme is repayment of obligations for some investors. Revenues and interest rates were payed off due to new financial contributions. Beginning in the 1920s similar financial schemes are forbidden by law in most developed countries. Despite it, however, financial pyramids emerge today [17].

Let us refer to the Russian experience of financial pyramids' functioning. In Russia, the CIS and Eastern European countries the first financial pyramids were organized in the transition period in the middle of the $90 \mathrm{~s}$, due to the change of the political and economic system [18, 19]. For many people transition to the market system associated with a large number of investment companies where money can be invested and profit can be gained.

The amount of damage caused by financial pyramids starting from 1991 amounts to 1983100 million of prerevaluation rubles and 14300 thousand US dollars. The number of Russians harmed by various financial pyramids' activity exceeds 20 million people. In 2008 law enforcement bodies outlawed 28 financial pyramids. Starting from 2009 twelve more financial pyramids were outlawed [20].

The main reasons for developing these schemes is unawareness of where, who and for what purposes people give their earned and saved money. Moreover, they cannot and do not know how to properly execute money transfer.

Characteristic features of a financial pyramid as compared to other financial institutions are as follows: a huge, incredible revenue with minimal risks is guaranteed in the promotion campaign of a financial pyramid; minimum primary inputs are required for joining a pyramid. Thus, a company can attract maximum participants, which makes it easier for them to put up later with money losses. An image of a highly professional financial organization is created, though its principles of performance are not explained. The following network marketing approaches are employed: extra payment of revenue is promised for involving every new participant in the scheme; absence of necessary licenses; performance obscurity. If a company has any of the signs, the risk of money loss increases greatly.

Let us study the basic strategies employed by financial pyramids to withdraw money from people. The first strategy is to use a modified name of a famous company, a popular brand. People might associate a pyramid with a respectable company under similar name, which enhances confidence. The second strategy is reference to well-known or unknown companies (the information about which is inaccessible) as business partners (incorporators). The third strategy is to produce an agreement to a customer only in the office or in 
person. Thus, a person has no possibility to study the terms of agreement or consult somebody. Moreover, under this agreement a company de facto is not responsible for preservation of money. Typically, people do not read an agreement properly even when they have it on hand. The fourth strategy is a demand for initiation fees payment. Generally, these fees are a main revenue of the organizers of the financial pyramid. The fifth strategy is high-pressure techniques and speculating on a man's daily needs, e.g. their need for money to pay back a loan, debts, tuition fees, buy an apartment, a car, etc. Organizers of financial pyramids can offer easy-term loans. For instance, to pay $30 \%$ of an accommodation cost, and provide the rest of money at $1-3 \%$ annual interest. It is to be noted, that currently there are no such interest rates on the market. Another sign of a financial pyramid is shared construction at dumping prices.

Consequently, entering a financial market an individual must consider these features, i.e. he must be able to compare the promised profit with the market return in this field of activity, review documents (an agreement, a license, etc.), study transaction terms. It requires a certain level of financial literacy. Possibilities for investing, saving, and crediting are countless. Therefore, a financially ignorant individual cannot understand what issues are worth considering when using financial instruments, and how to choose the most suitable options.

One of the ways to fight against financial pyramids is undoubtedly raising investors' literacy (namely, investors joining the schemes). Thus, in 2010 the Consumer Financial Protection Bureau was established in the USA. Its main tasks are promoting financial literacy programs for the public, collecting, investigating and addressing people's complaints, monitoring financial market sectors [21].

Rapid development of a financial services market followed by expansion of financial products assortment, complexities with their consumption (for senior citizens, in particular) due to the use of modern information technologies, emergency of new organizations on the market, etc. call for raising the level of financial literacy. Financially literate people are more protected from financial risks and emergencies. They are more responsible about managing personal finances, are able to improve their well-being due to redistribution of available financial resources and planning future expenditures. Decision-making based on financial knowledge guarantees financial safety and improvement of well-being, thus, contributing to the sustainable development of the economic system.

\section{Conclusion}

Due to the fact that the aim of raising individual financial literacy is providing any member of society with comprehensible quality information on time, we turn now to another issue allowing fighting financial illiteracy - information. Information allows reducing external influence on people's behaviour in a changeable environment and depends on development and application of new communication technologies for raising financial literacy.

Today, in Russia there is not a unified information environment for raising financial literacy. A unified environment means a complex of informational systems formed and used by all institutions (state, business, nongovernmental). On the one hand, we need a system incorporating information from banking, business, and state sectors, so that an individual could thoroughly assess a future financial transaction prior to decisionmaking. On the other hand, there must be an integrated information system ensuring the following: 1) continuing research on financial awareness; 2) moulding a national strategy, i.e. setting goals and tasks, a complex of arrangements, involving qualified specialists able to make arrangements and assess efficiency in order to find ways to improve the strategy; 3) developing standards distributed within the frameworks of educational informational programs of both governmental and nongovernmental organizations; 4) distributing information (organizing and maintaining universal distribution channels); 5) coordinating agents' activity with the aim of cost saving, in case of duplicating actions; 6) assessing the results of programs (governmental and non-governmental), aimed at raising financial literacy; 7) creating authoritative and accessible sources of information for consumers of financial services; 8) implementing educational programs (seminars, training sessions, etc.); 9) consulting and protecting consumers' rights when choosing and consuming financial services.

In our opinion, creating a common informational area on the base of e-government [22] will help generate all existing systems of information interchange, targeted at raising people's financial literacy. The aim of this association is to develop and jointly implement the strategy intended to correct imbalance of a person's social and economic (financial) behaviour in a changing society. Information must be accessible for every institution, aimed at raising financial literacy.

It is significant that creation and development of a common information area will mitigate diseconomies resulting from low level of financial literacy for all market participants. Firstly, negative consequences for population consuming financial services are as follows: 1) inefficient decisions undermining confidence in financial institutions; 2) inability to take advantages of the financial market; 3) a high level of personal debentures; 4) mass bankruptcy of legal persons; 5) transfer of negative financial experience to the younger generation; 6) susceptibility to the risks of fraud and inequitable conduct of financial services providers; 7) low savings for vital tasks; 8) inefficient pension saving and management schemes. Secondly, low level of financial literacy prevents the state from developing a financial sector in general, making arrangements on raising effectiveness of financial market regulation, developing a system of institutions protecting customers' rights, transition to the pension scheme based on individual contributions of every member of society. Thirdly, a common information area will allow private institutions providing financial services to reduce 
competitiveness of unscrupulous providers of financial services and enhance confidence in the financial sector.

It is necessary to determine some steps for improving individuals' well-being when fighting financial illiteracy. Obviously, individuals must regulate their income and expenditure, take not less than three days for investment decision-making (consider the idea, gather information, and make a decision). When executing a transaction a written agreement must be made, all terms of agreement must be specified, additional information about an organization raising investments, its owners and results of previous activity must be thoroughly explored.

Therefore, a common information area provides for making financially wise decisions in the current changing environment. A customer obtains necessary information about financial products, consuming methods and organizations providing these services. Consumers' involvement in the information area will increase the level and quality of their savings and investments, influencing a country's economic growth, increase of social and economic well-being of every member of the society.

\section{References}

1. M. Verbic, T. Stanovnik, Eastern European Economics, 44, 60-70 (2006)

2. A. Ferrer-i-Carbonell, J. Public Econ, 89(56), (2005).

3. A. Ferrer-i-Carbonell, Income and Wellbeing. Tinbergen Inst. Discuss. Pap. (2002)

4. Hayo, Bernd; Seifert, W. W. Subjective economic wellbeing in Eastern Europe. Diskuss. aus dem Fachbereich Wirtschaftswissenschaften, Univ. Gesamthochschule

EssenWirtschaftswissenschaften, Univ.

Gesamthochschule - Ess. (2002)

5. C. Senik, Relativizing Relative Income. (2004)

6. E. Diener, et al. Assessing Well-Being, 39, (2009)

7. E. Diener, W. Tov, J. Soc. Issues, 63, 421-440 (2007)

8. Financial Literacy Statistics - DollarCamp \& JumpStart - Documents. Documents.mx (2014). at $<$ http://documents.mx/documents/financial-literacystatistics-dollarcamp-jumpstart.html $>$

9. S. Dutta, T. Geiger, B. Lanvin, The global information technology report 2015

10. E. Johnson, M. S. Sherraden, E. Johnson, J. Sociol. Soc. Welf, 34, 119-145 (2007)

11. S. M. Danes, H. R. Haberman, Teen Financial Knowledge, Self-Efficacy, and Behavior: A Gendered View. Financ. Couns. Plan, 48-60 (2007)

12. D. L. Remund, Financial Literacy Explicated: The Case for a Clearer Definition in an Increasingly Complex Economy. J. Consum. Aff., 44, 276-295 (2010)

13. Controversial financial literacy of Russians. Nacfin.ru (2015). at $<$ http://nacfin.ru/protivorechivaya-finansovayagramotnost-rossiyan/>
14. E.R. Kashapova, M.V. Ryzhkova, TSU J. of Economics, 30, 15-26 (2015)

15. M.K. Lewis, Accounting Forum, 36 294-309 (2012)

16. T. Frankel, Statement of Tamar Frankel before the Committee of Financial Services of the US House of Representatives

$<$ http://archives.financialservices.house.gov/media/f ile/hearings/111/franke1010509.pdf>

17. D. Tennant, J. Int. Financ. Mark., Institutions and Money, 21 (3), 328-346. (2011)

18. M. Mugo, Int. Spect. Ital. J. Int. Aff. 33, 105-116 (1998)

19. K. Verdery, Comparative Studies in Society and History, 37(4), 625-669. (1995)

20. The data of Economic Security Department of the Ministry of Internal Affairs of the Russian Federation

21. The Dodd Frank Wall Street Reform and Consumer Protection Act of 2010. 12 U.S.C. at $<$ https://www.gpo.gov/fdsys/pkg/PLAW-

111publ203/pdf/PLAW-111publ203.pdf $>$

22. T. V. Filippova, Procedia - Soc. Behav. Sci., 166, 526-529 (2015) 